NOTICE

PORTIONS OF THIS REPORT REE ILLEETSE ? PORTIONS Of THIS REPORT
has been reproduced from the tesi at ave to permit the broadest possible avail.
copy to

LA--1006I-SR

ability.

DE8 4014143

\title{
Materials Science and Technology (MST) Division Nuclear Materials Process Technology Group (MST-12) Chemical Process Research and Development Report
}

David G. Clifton

\section{DISCLAIMER}

This report was prepared as an account of work sponsored by an agency of ibe United States Gowernment. Neither the United States Government nor any aseacy thereof, nor any of their employees, makes any warranty, express or implied, or assumes any legal liability or reeponaibility for the accuracy, completencas, or usefulness of any information, apparates, product, or process disclosed, or represents that its use would not infringe privately owned rights. Refoxcsce berein to any specific commercial product, procesa, or service by trade uame, trademark, manufacturer, or otherwive does not necesarily conetitute or imply its endorecenent, reacmmendation, or favoring by the United States Goverament or any agency thereof. The visur. and opinions of authors expresed herein do not necessarily state or reflect thone of the United States Government or any agency thereof.
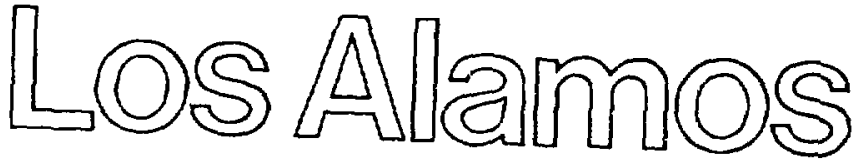

Los Alamus National Laboratory Los Alamos, New Mexico 87545 


\title{
MATERIALS SCIENCE AND TECHNOLOGY (MST) DIVISION
}

NUCLEAR MATERIALS PROCESS TECHNOLOGY GROUP (MST-12)

CHEMICAL PROCESS RESEARCH AND DEVELOPMENT REPORT

by

David G. Clifton

\begin{abstract}
- A process for the recovery of plutonium and americium from molten salt extraction (MSE) salt residues has been demonstrated. It is based upon a new chloride anion-exchange process at low acidity that eliminates corrosive $\mathrm{HCl}$ fumes.

- The Los Alamos americium oxide production line has been improved to give more product with a concurrent lowering of personnel radiation exposure.

- A cost study has been made for the disposal of americium-contaminated calcium metal buttons that were obtained by pyrochemical recovery of plutonium from MSE salts. The waste form used in the study conforms to WIPP-Facility standards and current stateof-the-art radioactive waste disposal. The cost estimate is $\sim \$ 300 / \mathrm{g}^{241} \mathrm{Am}$.

- Plutonium decontamination factors of $\sim 300$

have been obtained from lead-platinum alloy dissolution experiments carried out in alumina crucibles using lead oxide slag to getter the plutonium.
\end{abstract}

\section{INTRODUCTION}

The Nuclear Materials Process Technology Group (MST-12) currently has the responsibility for five major programs: 
- Plutonium Dioxide Production for the Fast Flux Test Facility (FFTF) Reactor

- Plutonium Scrap Recovery

- Uranium Scrap Recovery

- Americium Recovery and Purification

- Uranium Metal Production

The group conducts supporting chemical process research and development (R\&D) projects that provide resources for the continual maintenance, upgrading, and innovation that are necessary to keep the major programs current with advanced technology.

This report gives the status of the plutonium R\&D projects but does not directly address the position of major programs (e.g., production goals, problems, and outputs). These are reported elsewhere.

I. PLUTONIUM AND AMERICIUM RECOVERY FROM MSE RESIDUE SALTS:

Larry R. Avens and David G. Clifton

The pyrochemical MSE process extracts americium from liquid plutonium metal using a molten mixture of sodium, potassium, and magnesium chlorides. This gives a plutonium metal button with lowered americium content and salt residues containing sodium, potassium, magnesiun, americium, and plutonium chlorides. 1 Because of poor physical separation of molten metal from salts, the residues may include small beads of plutonium or plutonium oxide particles resulting from metal bead oxidation.

At Los Alamos over 100 MSE residues containing $\sim 12 \mathrm{~kg}$ of plutonium and 400 to $600 \mathrm{~g}$ of americium are stored in the vaults. This backlog is small compared with $\sim 20$ metric tons of residues containing 1 metric ton of plutonium and $\sim 70 \mathrm{~kg}$ of americium stored at Rocky Fiacs Plant (RFP).

Over the years, RFP has recovered actinides from these high-chloride wastes using several approaches with mixed success.

1. Dissolution of MSE salts in HCl, precipitation of the actinides with $\mathrm{KOH}$, filtration, redissolution of the separated hydroxides in $\mathrm{HNO}_{3}$, and then separation of the americium trom plutorium with hexanitrato-anionexchange chromatography were accomplished. The eluted plutonium then went 
to the main plutonium recovery process, but the feed and wash effluents containing the americium were sent to thiocyanate ion-exchange columns for americium recovery. 2

2. Later, the caustic precipitation step (see above paragraph) was replaced with cation-exchange columns. 3 The dissolved salts, in very dilute solutions, were loaded onto cation-exchange columns to get rid of the chloride ions, and the actinides were eluted from these

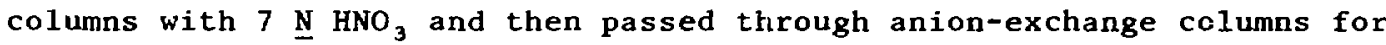
americium and plutonium separation. The effluent americium was then precipitated as the oxalate and calcined to oxide.

3. A combination anion exchange with either an extractionchromatography procedure or a liquid-liquid extraction approach recently has been studied but has not yet been put into production. 4

4. Present pyrochemical approaches to the problem focus on metallic plutonium recovery that requires subsequent purification to remove americium from the plutonium button. Also, most of the americium ultimately is in a mixed metal alloy that is either buried or requires special processing to obtain pure americium.

A. New Process for MSE Salt Residues

Recovery of both plutonium and americium from MSE salt residues using a new chloride anion-exchange process at low acidities that eliminates corrosive $\mathrm{HCl}^{\prime}$ fumes has been demonstrated at Los Alamos. The new process takes advantage of the high-chloride salt content of the MSE residue salts and gives only discardable low-level wastes plus the two products, plutonium dioxide and americium nitrate in nitric acid solution, for the $\mathrm{AmO}_{2}$ production line.

The process flow sheet given in Fig. 1 is as follows: Broken MSE salt cake and crucible pieces undergo dissolution and leaching with HNO, until the solution is $\sim 1$ to $2 \underline{N}$ and almost saturated with salt at room temperature. The filtered Iiquid is collected and appropriate amounts of $\mathrm{NaNO}_{2}$ are added to adjust the plutonium to Pu IV. Since the solution has high-chloride levels $(C 1 \sim 5 \underline{M})$ as it flows through a Dowex $1 \times 4$ resin column in the chloride form, $P u C 1_{6}=$ is sorbed, and the americium, magnesium, and other salts exit in the effluent. The resin bead-invading 


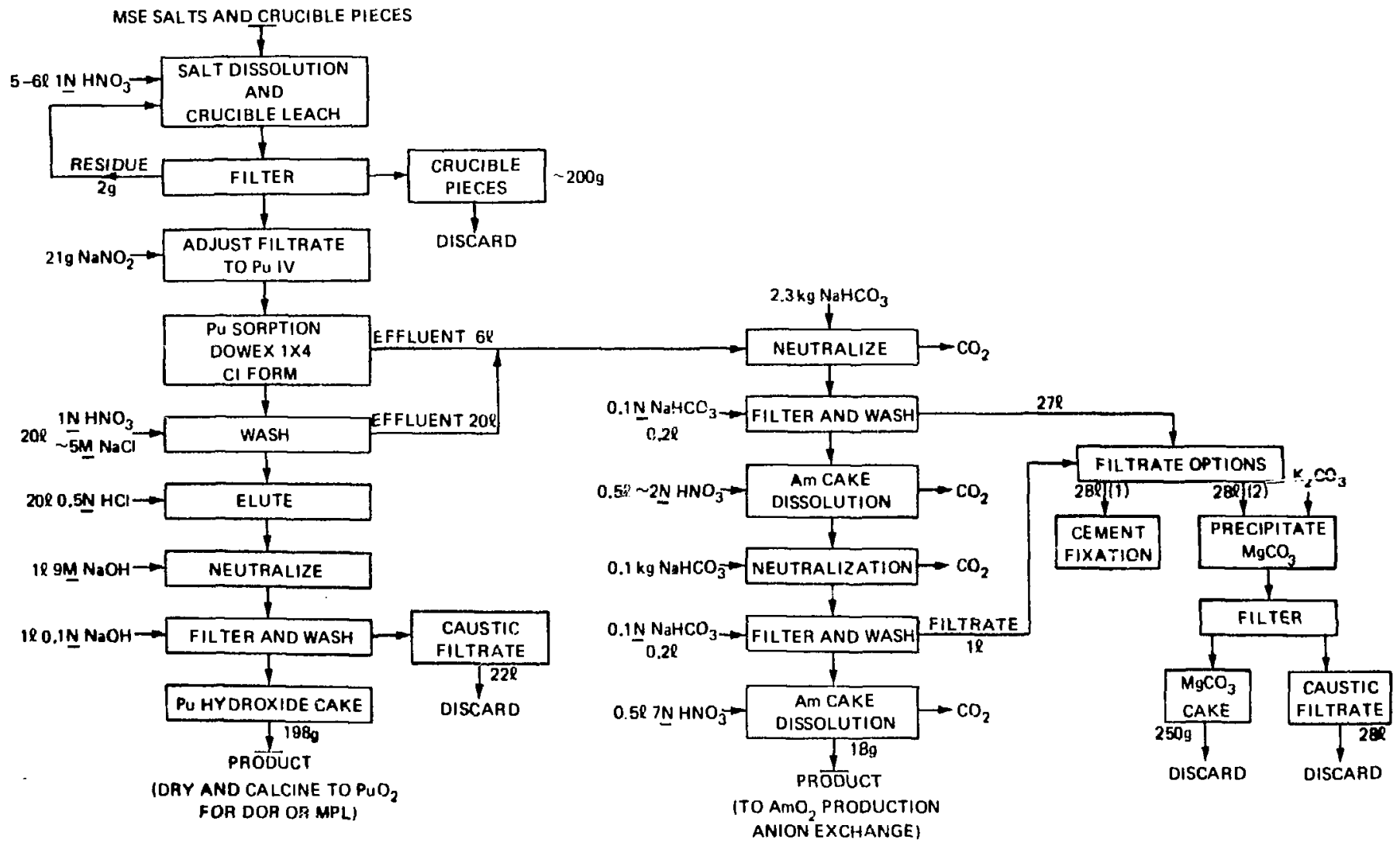

Fig. 1. Flow Diagram: Plutonium and Americium Recovery from Molten Salt Extraction Residues ( $2 \mathrm{~kg}$ MSE Salt Cake Containing $200 \mathrm{~g} \mathrm{Pu}$ and $20 \mathrm{~g} \mathrm{Am}$ ). 
americium, magnesium, and other salts are washed from the column with $1 \underline{\mathrm{N}} \mathrm{HNO}_{3}-4.8 \underline{\mathrm{M}} \mathrm{NaCl}$.

The clean plutonium on the resin is eluted with $0.5 \mathrm{~N} \mathrm{HCl}$, precipitated with $\mathrm{NaOH}$ as the hydroxide, filtered, washed, dried, and calcined to a $\mathrm{PuO}_{2}$ product. The filtrate is discardable and the resin is ready for another loading.

The combined feed and wash effluents contain the americium; magnesium; some plutonium; and the hydrogen, potassium, sodium, chloride and nitrate ions. A moderate rate of addition of solid $\mathrm{NaHCO}_{3}$ to this solution neutralizes it and releases $\mathrm{CO}_{2}$ without excessive frothing. Further addition of $\mathrm{NaHCO}_{3}$ to saturation precipitates the americium and plutonium, while the magnesium stays in solution and goes with the filtrate. This occurs because the solution has a $\mathrm{pH}$ of 8 to 9 at saturation with $\mathrm{NaHCO}_{3}$.

The americium product cake may be redissolved with minimal nitric acid and reprecipitated with $\mathrm{NaHCO}_{3}$ to lower any magnesium contamination, if deemed necessary. This filtrate is combined with the first one and is discardable.

The final americium cake is dissolved with nitric acid, adjusted to $7 \underline{N}$, and sent to the head-end anion-exchange column of the americium production line, where it is cleaned of any residual plutonium and then converted through the oxalate to americium dioxide.

Two options for filtrate treatment are either cement fixation of the liquid and burial or precipitation of the magnesium as a reasonably filterable carbonate by the addition of sodium or potassium carbonate followed by filtration. This filtrate is discardable as caustic waste, while the wet cake is a low-level contaminated solid that can be stabilized for hurial by calcination to $\mathrm{MgO}$.

If it is not desired to recover the americium, addition of sodium or potassium carbonate to the combined feed and wash effluents precipitates americium, plutonium, and magnesium as readily filterable materials. This cake can be stabilizea by calcination to a solid form, presumably MgO contaminated with americium and plutonium oxides, for storage as fairly high-level contaminated waste. 


\section{B. Experimental Results on MSE Salt Residues}

\section{Salt Dissolution and Crucible Leach}

Two MSE salt residues, XBLP 217 and 143, from vault storage were studied experimentally, with the results shown in Table I.

Gamma radiation levels of 100 to $300 \mathrm{mrad} / \mathrm{h}$ were measured for these residues, so shielding precautions were necessary in handling them.

Dissolution of random samples of the broken salt pieces with minimal quantities of $1 \underline{\mathrm{N}_{\mathrm{HNO}}} \mathrm{H}_{3}$ went smoothly with very little gas release, minor heat release, and little residue. Initially, blue $\mathrm{Pu}$ III was seen, but it slowly changed to blue green and then to green as presumably it was oxidized to $\mathrm{Pu} I V$. The addition of $\mathrm{NaNO}_{2}$ ensures that this oxidation takes place. As the chloride concentration increased during dissolution, the red-brown $\mathrm{PuCl}_{6}=$ complex seemed to form.

Later tests with other MSE salts showed that if appreciable amounts of plutonium metal or oxides are present, they consume the hydrogen ion in reaction; dissolution in 2 to $4 \mathrm{~N}_{\mathrm{HNO}_{3}}$ is necessary to obtain a final feed solution that is 1 to $2 \mathrm{~N}$ in hydrogen-ion concentration.

When $4.9 \mathrm{~g}$ of XBLP 217 was dissolved in $15 \mathrm{me}$ of added $1 \mathrm{~N} \mathrm{HNO}_{3}, 16.5$ ml of a solution $4.15 \underline{M}$ in chloride ion was found; it is probably marginal for sorption of the Pu complex on chloride-form anion resin. (Note the liquid volume increase of $\sim 10 \%$ upon dissolution.) Here, an amount of black residue left on a fine-fritted glass filter after solution clarification by filtration was too small for characterization.

Next, $\sim 30 \mathrm{~g}$ of broken MgO crucible pieces were leached in $1 \mathrm{~N} \mathrm{HNO}_{3}$. The gamma radiation of the crucible pieces dropped from $120 \mathrm{mrad} / \mathrm{hr}$ to 6 madr/hr after 3 minutes of leaching and finally decreased to $1 \mathrm{mrad} / \mathrm{hr}$ (or background leve1) after an additional 45 minutes of leaching.

A 21.6-g salt piece dissolved in 55 ml of $1 \mathrm{~N} \mathrm{HNO}_{3}$ gave a volume of $62.7 \mathrm{ml}(\sim 14 \%$ increase) with the temperature increasing from 23 to $26^{\circ} \mathrm{C}$ in $\sim 20$ minutes. Solution filtration left $\sim 100 \mathrm{mg}$ or $\sim 0.5 \%$ of black residue. The assay of this solution gave a chloride concentration of $5.4 \underline{M}$, which should provide good anion-exchange sorption. This saltto-acid ratio corresponds to dissolving a $2-\mathrm{kg}$ salt cake in $\leqq 6 \ell$ of $1 \underline{N}$ $\mathrm{HNO}_{3}$ and leaving $10 \mathrm{~g}$ of black residue. 
TABLE 1

MSE SALT AND CRUCIBLE RESULTS

CHM- 1 SOLUTION ASSAY RESULTS

\begin{tabular}{|c|c|c|c|c|c|c|c|c|c|}
\hline $\begin{array}{l}\text { MSE RESIDUE } \\
\text { I.D. }\end{array}$ & $\begin{array}{c}\text { SALT } \\
W T \\
8 \\
\end{array}$ & $\begin{array}{l}\text { FINAL } \\
\text { SOLN VOL } \\
\quad \ell \\
\end{array}$ & $\begin{array}{l}\text { SOLN } \\
\text { CONC } \\
\text { B SaIt/e }\end{array}$ & $\begin{array}{l}\text { SAMPIE } \\
\text { NO. } \\
\end{array}$ & $\begin{array}{l}\mathrm{Pu} \\
\mathrm{B} / \underline{\ell}\end{array}$ & $\begin{array}{l}\mathrm{Am} \\
\mathrm{g} / \mathrm{l}\end{array}$ & $\frac{\text { CHLORIDE }}{B / \ell}$ & $\frac{\mathrm{UN}}{\underline{\mathrm{M}}}$ & $\begin{array}{l}\text { RATio } \\
\text { Pu/A= }\end{array}$ \\
\hline XBLP $21 i$ & 4.9 & 0.0165 & 297. & 234 & 11.2 & 0.881 & 147 & 4.15 & 12.7 \\
\hline XBLP 217 & 1.2 & 0.110 & 10.9 & 235 & 3.12 & 0.253 & 1.6 & 0.045 & 12.3 \\
\hline XBL.P 217 & 21.6 & 0.0627 & 344. & 237 & 15.0 & 1.09 & 192. & 5.4 & 13.8 \\
\hline XBLP 217 & 12.7 & 0.037 & 343. & 246 & 14.1 & 1.10 & 185. & 5.2 & 12.8 \\
\hline XBL.P 217 & 10.1 & 0.047 & 215. & 255 & 33.6 & 0.81 & 95. & 2.68 & 41.5 \\
\hline XBLP $: 43$ & 0.2 & 0.0265 & 347. & 256 & 22.1 & 5.96 & 180. & 5.08 & 3.71 \\
\hline XBLP 143 & 5.5 & 0.0155 & 355. & 264 & 21.0 & 6.60 & 195. & 5.5 & 3.18 \\
\hline
\end{tabular}


The XBLP 217 salt was black but also some green powder, suspected to be rich in $\mathrm{PuO}_{2}$, was in the bottom of the container. This may have resulted from oxidation of finely divided plutonium metal. Dissolution in $1 \mathrm{~N}^{\mathrm{HNO}_{3}}$ was rapid with grey froth formation; only blue Pu III color was seen after several hours at $23^{\circ} \mathrm{C}$, and considerable residue that looked like $\mathrm{PuO}_{2}$ was found. This residue needs further study.

Table I shows that random samples of XBLP 217 salts gave a fairly constant Pu-to-Am ratio of $\sim 13$ except for the powder in the can bottom, which was richer in plutonium. The table also shows that the attained salt concentrations for the solutions are high enough for good resin sorption of the plutonium.

Another vault-stored MSE salt residue, XBLP 143, was examined and found to be analogous to XBLP 217. Dissolutions in 1 N HNO 3 went smoothly, giving solutions above $5 \underline{M}$ in chloride-ion concentration. Crucible pieces were effectively leached in dilute $\mathrm{HNO}_{3}$, and only small amounts of residues remained after filtration. One residue that remained from a dissolution in $10 \underline{\mathrm{N}} \mathrm{HNO}_{3}-0.05 \mathrm{~N}$ HF was assayed as having $5.03 \mathrm{~g}$ $\mathrm{Pu} / \ell, 0.0088 \mathrm{~g} \mathrm{Am} / \ell$, and $0.000127 \mathrm{~g}$ chloride/l, so the plutonium has only $1750 \mathrm{pprn}$ Am and less than $30 \mathrm{ppm}$ chloride; therefore, it can be added to regular plutonium-process streams.

Table I shows the plutonium-to-americium ratio to be different for the two cakes; however, this is to be expected as it is a function of the cakes' previous history.

Estimates from the acquired tabulated data for XBLP 217 give $41 \mathrm{~g}$ Pu and $\sim 3 \mathrm{~g}$ Am per $\mathrm{kg}$ of salt, while XBLP 143 gives $\sim 61 \mathrm{~g}$ Pu and $\sim 18 \mathrm{~g}$ Am per $\mathrm{kg}$.

2. Process Tests on MSE Salt Residues Using Fig. 1 Flow Sheet Portions of salts from XBLP 217 and 143 were dissolved in $1 \underline{N} \mathrm{HNO}_{3}$, filtered, and the valence adjusted to $\mathrm{Pu} I V$ by the addition of $\mathrm{NaNO}_{2}$. These solutions were passed dircctly through a column of chloride-form Dowex $1 \times 4$ anion-exchange resin and processed as shown in the Fig. 1 flow sheet. Table II lists the experimental data obtained.

Only a portion of the solution that was obtained by the dissolution of $12.7 ;$ of salt was used in Experiment 17 to avoid column overload. 
TARLE II

PROCESS TESTS ON DJSSOLVED MSE SALTS

STREAM

Pu (8/8)

An $(8 / 2)$

$\underline{M}(8 / \ell)$

Vol (l)

$\underline{\text { Pu }(g)}$

An (8)

$\underline{M g}(8)$

pum Aun

egm Pu

$\operatorname{pem} M_{8}$

EXPERIMENT 17 (XBLP 217 SALT)

Feed

\begin{abstract}
1.10
\end{abstract}

$-$

0.0265

0.374

0.0291

Eluace

Bicarb ppt Dis- $\quad 0.0676$

5.22

0.327

-

0.0925

0.00140

0.0302

00095

0.011

0.081

0.423

0.0000775

0.021

0.00142

0.0353

0.000891

0.000693

Bicarb ppt Filtrate 0.000805

0.00144

$-$

0.117

0.0000942

0.0165

0.000666

0.000168

2nd Bicarb ppt

0.0404

1.54

0.012

0.005120 .00581

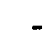

2nd Bicarb ppt Filtrute

Eluate ppt Dis-
solved

17.7

0.00372

0.034

0.0235

0.000120

0.0254

0.000198

0.000137

$\mathrm{K}_{2} \mathrm{CO}_{3} \mathrm{ppt}$

0.000727

0.000166

0.012

0.022

0.389

0.0000818

0.110

0.0000800

0.0000183

0.00132

\title{
EXPER IMENT 18 (XBLP 143 SALT)
}

Feed

Effluent and wash

22.1

Eluate

Bicarb ppt

Dissolved

Bicarb ppt

Filtrate

2nd Bicarb ppt

Dissolved

2nd Bicarb ppt

0.121

5.96

1.71

0.0265

0.586

0.158

9.73

0.406

0.00624

$-$

0.085

0.0103

0.145

6.28

0.009

0.081

0.788

0.000505

0.00893

0.138

0.101

0.000518

0.00000048

0.239

4.29

0.020

0.029

0.00693

0.124

0.00058

0.0000980

Filtrale

Eluate ppt

21.4

0.0146

0.048

0.032

0.685

0.000467

$-$

0.000729

0.00114

$$
-
$$

641

-
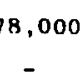

1801

$-$

$-$

40,200

2,100

19,600

$-$

$-$

26,200

7800

$-$

2101

1923

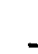


The ilutrinium product contained 2200 ppm Am vs a value of 78,000 ppm for the reed and it had $\sim 2000 \mathrm{ppm}$ magnesium. The plutonium yield was alculated and found to be greater than $100 \%$, indicating assay problems. An americium yield of $\sim 87 \%$ is based upon data for the feed and the solution obtained by dissolution of the second bicarbonate precipitate. Again, srattered assay results are a problem. The americium product had $\sim 4 i, 000$ and $\sim 27,000 \mathrm{ppm}$ plutonium after the first and second bicarbonate precipitations, respectively.

In Experiment 18 , the plutonium product had $\sim 700 \mathrm{ppm}$ vs $\sim 270,000$ ppm americium in the feed, and again the calculations give a yield greater than $100 \%$. The americium yield after the second bicarbonate precipitation was $\sim 78 \%$ and contained $\sim 56,000 \mathrm{ppm}$ plutonium.

The present americium dioxide production line uses feeds that contain up to $\sim 200,000 \mathrm{ppm}$ or $20 \%$ plutonium; therefore, it can handle the americium product stream shown in the flow sheet.

The magnesium results in Table II show that the americium product contains magnesium levels above specifications of $5000 \mathrm{ppm}$. A second precipitation with the bicarbonate lowers magnesium by about a factor of 1/2. It is assumed that further magnesium decontamination will occur during the americium oxalate precipitation; in fact, it should obviate the second bicarbonate precipitation.

These two tests using actual MSE salt residues gave excellent and easy plutonium recovery with high yields and quite acceptable product purity. Americium yields are acceptably high, although scattered assay results preclude firm yield figures; however, high yields are supported by the very low concentrations found in the discardable filtrates. P1utonium contamination of the americium product stream requires that it be processed through the americium dioxide production line hexanitratoanion-exchange system.

\section{Additiona1 Experiments}

Los Alamos MSE salt residues contain $\sim 8$ wt\% magnesium chlorige, so most simulated tests to date were done at this leval. Residues at kFP can run as high as $30 \mathrm{wt} \% \mathrm{MgCl}_{2}$; therefore, additional experiments, one at $\sim 25 \mathrm{wt} \%$ and a couple at $\sim 5 \mathrm{wt} \%$ magnesium chloride, were performed with sirulated MSE salts. 
At the higher magnesium chloride level, better separation of plutonium and americium was observed, presumably because of the overall increase in chioride concentration. Th: americium product contained only $\sim 6 \%$ plutonium vs values of $\sim 10$ to $20 \%$ that occurred in some lower magnesium chloride tests. Also, the plutonium seemed to sorb more tightly on the column (i.e., in a narrower band) and yield figures were $\sim 99 \%$ for plutonium and $\geqq 90 \%$ for americium. The americium product obtained from only one bicarbonate precipitation contained 33,000 ppm magnesium; this is considered to be high.

Tests with lower magnesium chloride concentrations and consequently lower chloride ion levels gave lower plutonium product yields because of losses to the americium fraction. A plutonium yield of $\sim 98 \%$ with $\sim 440$ ppm americium in the plutonium fraction and an americium yield of $\sim 98 \%$ with $\sim 11 \%$ plutonium in it are typical results for a low-magnesium chloride test. The magnesium levels in the products are not yet known because of delays in receiving assay results.

From these tests, it is concluded that high-magnesium chloride levels in the MSE salts enhance the plutonium-americium separation.

a) Tests of magnesium cleanup from the americium product have given mixed results, as is evident in Table II. Difficulties experienced in obtaining reliable magnesium assays have contributed to these ambiguities.

One series of tests of magnesium cleanup from americium product by a second bicarbonate precipitation showed decreased magnesium values ranging from $13,000-?_{1}, 000 \mathrm{ppm} \mathrm{Mg}$ in the first product to values of $\sim 1700-4500 \mathrm{ppm}$, respectively, in the second product; magnesium was reduced by a factor of $\sim 0.2$ vs the value of $\sim 0.5$ seen in Table II.

Further magnesium-decontamination studies are necessary to substantiate cleanup of the americium by both bicarbonate and oxalate precipitations.

b) Filterability tests were made of magnesiun precipitates obtained from nonradioactive solutions simulating the filtrates that are shown in the Fig. 1 flow sheet. Precipitants used to form filterable 
magnesium compounds were KF, $\mathrm{NaOH}, \mathrm{K}_{2} \mathrm{CO}_{3}, \mathrm{Na}_{2} \mathrm{HPO}_{4}$, and $\mathrm{K}_{2} \mathrm{C}_{2} \mathrm{O}_{4}$. A comparison of filtration times and the per cent of original magnesium precipitated under ambient conditions indicated that $\mathrm{K}_{2} \mathrm{CO}_{3}$ gave the best precipitate. Therefore, for final magnesium cleanup of filtrates, it is recommended thiat it be precipitated as the carbonate, iried, calcined to $\mathrm{MgO}$, and then buried as a contaminated, stabilized solid.

\section{REFERENCES}

1. J. B. Knighton, R. G. Auge, and J. W. Berry, "Molten Salt Extraction of Americium from Molten Plutonium Metal," Rockwell International, Atomics International Division, Rocky Flats Plant report RFP-2365 (March 1976).

2. F. J. Miner, "Chenistry Research and Development Annual Progress Report, Nov. 1, 1979 to Oct. 31, 1980," Rockwell Internationa1, Atomics International Division, Rocky Flats Plant report RFP-3180 (August 1981), p. 21.

3. S. G. Proctor, "Cation Exchange Process for Molten Salt Extraciion Residues," Dow Chemical, Rocky Flats Division report RFP-2347 (March 1975).

4. L. L. Martella, J. D. Navratil, and M. T. Saba, "Recovery of Plutonium and Americium from Nitric Acid Waste Streams," in Actinide Recovery from Waste and Low-Grade Sources, J. D. Navratil, W. W. Schulz, and A. E. Talbot, Eds., Proc. of the Intern'1. Symp. Cosponsored by Div. of Ind. and Eng. Chem. and Nuclear Chem. and Tech. of the Amer. Chem. Soc. in NYC, August 24-25, 1981 (Harwood Academic Publishers, New York; 1982), p. 27. 
II. AMERICIUM OXIDE PRODUCTION AT LOS ALAMOS: Thomas W. Blum, John L. Parker, Marvin K. Romero, and Deidra D. Yearwood

Los Alamos National Laboratory supplies kilograms per year if highpurity americium dioxide to Oak Ridge National Laboratory for distribution through the isotope pool. Figure 2 shows the flow sheet for this production.

Within the past year, studies of the process have resulted in the considerable achievements shown in Figs. 3 and 4; namely, the output quantity was increased 2.5 times and concurrently worker's radiation dosage was reduced by a factor of $1 / 4.1$

These accomplishments (detailed in Ref. 1) resulted from the following:

- A1l input and output streams were systematically sampled and the contents assayed. From these results and appropriate mass balances, the necessary operational changes were made to successfully optimize the process.

Considerable modification and redesign of equipment were done to increase shielding from radiation and to decrease the operator's exposure time by reducing the number of manual operations. This includer use of Teflon-coated lead sheets wrapped around columns and tanks for shielding, a new design for a closed filtering system that eliminated a significant amount of operator attendance, and a smaller closed anionexchange column with simpler flow controls that required fewer manipulations .

\section{REFERENCES}

1. Thomas W. B1um, John L. Parker, Marvin K. Romero, and Deidra D. Yearwood, "Americium Oxide Production at Los Alamos National Laboratory: Recovery Up--Exposures Down," Los Alamos National Laboratory document LA-UR-83-2962 (November 1983). Presented at American Nuclear Society Meeting, San Francisco, California, October 30 to November 4, 1983. 


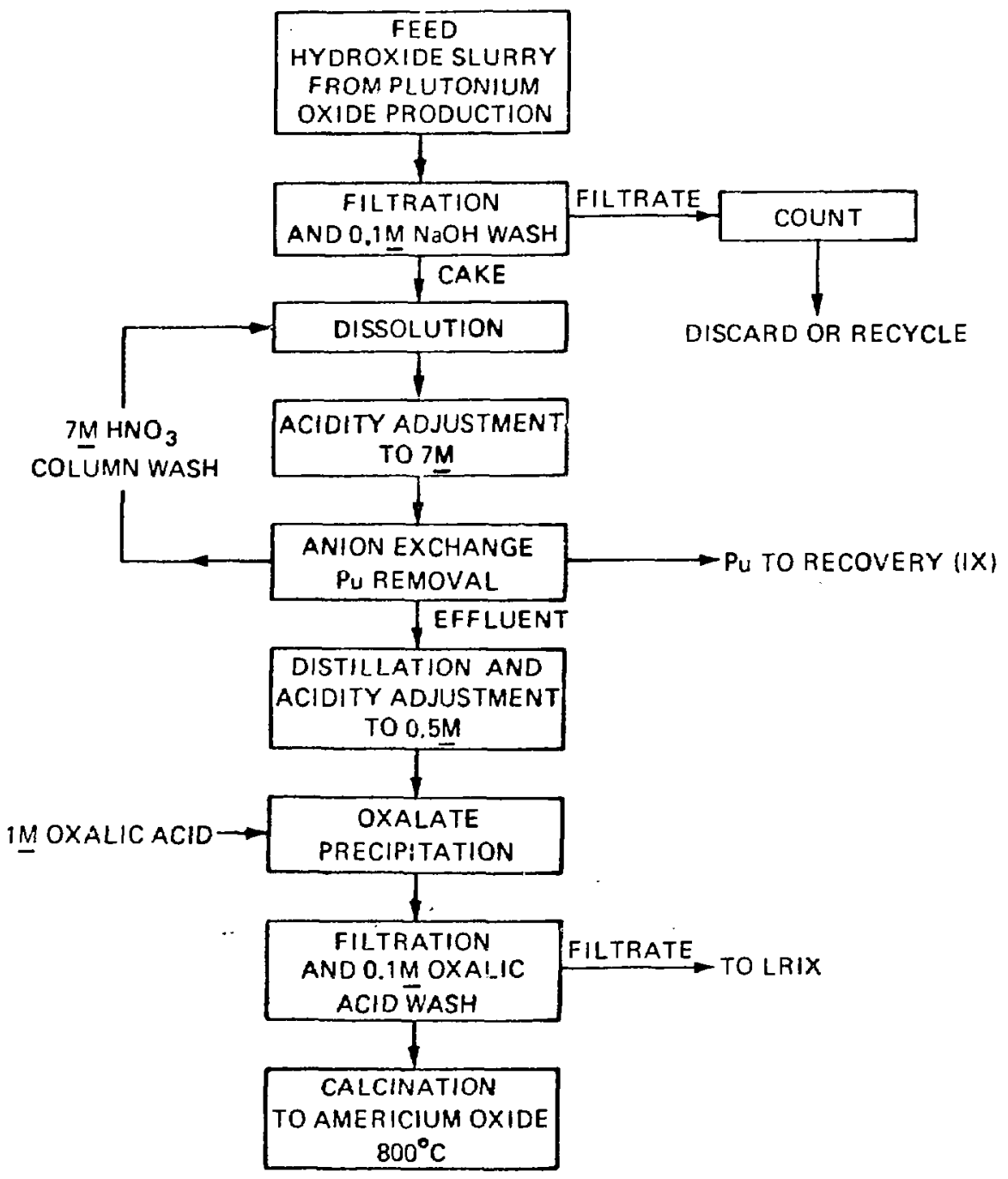

Fig. 2. Los Alamos Americium oxide Production 


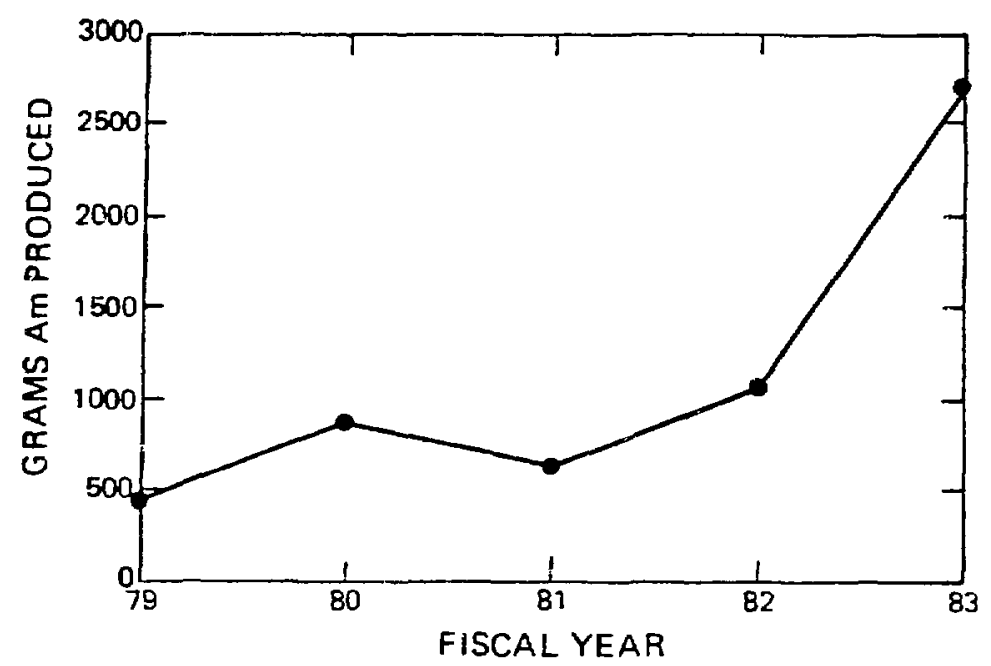

Fig. 3. Americium Production at LANL for Fiscal Years 1979 - 1983.

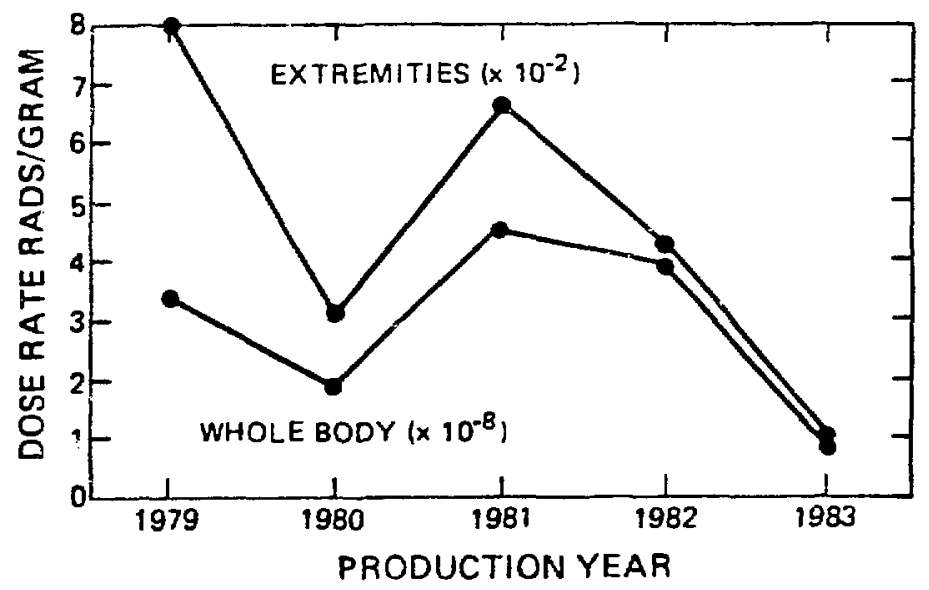

NOTE: RADIATION DATA FOR PRODUCTION YEAR 1983 IS CURRENT THROUGH 7-1.83. DATA POINTS STANDARD. IZED BY DIVIDING THE AVERAGE WORKER DOSAGE BY THE TOTAL GRAMS AMERICIUM PRODUCED.

Fig. 4.. Dosage Rate per Gram Am Produced. 
III. DISPOSAL COST ESTIMATE FOR AMERICIUM-CONTAMINATED CALCIUM METAL BUTTONS RESULTING FROM PYROCHEMICAL RECOVERY OF PLUTONIUM FROM MSE SALTS: C. L. Foxx

A detailed study has been completed that gives an updated americium disposal cost estimate that reflects the requirements imposed by the Waste Isolation Pilot Plant--Waste Acceptance Criteria (WIPP-WAC). 1

Certain initial assumptions were needed $f:$ chis study. One of the first, for disposal of americium-contaminated ciricium metal buttons, was to eliminate their potential pyrophoricity with controlled calcination to stable oxides; second, any dispersible powders formed were immobilized by cement fixation of these oxides. Other than this head-end treatment for calcium buttons, the considerations of the study apply to any americium-containing cement disposal.

The packaging requirements for shipping were examined for two waste categories: Remote Handled Transuranic Waste (RH TRU) and Contact Handled Transuranic Waste ( $\mathrm{CH}$ TRU).

Within each category, a number of factors such as curie limit, number of shipments, gas generation limit, surface dose rate limit, and weight limits were considered.

Calculations showed which of the above became the limiting factors for each mode of shipment. The RH TRU option was eliminated because the number of canister shipments necessary to accomnodate the canister curie limits was unacceptable.

It was concluded that the CH TRU category would apply to shipments from Los Alamos, and the limiting factor for these shipments was the gas generation limit. This imposed an americium value of $16.4 \mathrm{~g} /$ drum. Calculations based on this gave a cost of disposal of $\sim \$ 300 / 8$ americiun.

Characteristics of a typical americium waste drum, detailing some aspects of drum pressurization and potential hydrogen evolution, are also presented.

An overall estimate was given that disposal of approximately $43 \mathrm{~kg}$ of americium would require $\sim 2600$ 55-gallon drums . 
1. C. L. Foxx, "Cost Estinate for Disposal of a Calcium Metal Concentrate Enriched in fmericium-241, Resulting from Pyrachemical Recovery of Plutonł um from Molten Salt Extraction (MSE) Residues," Los Alamos National Laboratory Internal Memorandum, MST-12, Symbol MST-12-PS-83-114, t, Carolyn A. Mangeng, S-4, MS F611 (October 26, 1983).

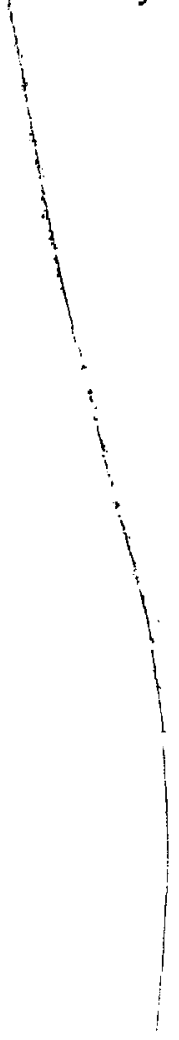


IV. PLUTONIUM DECONTAMINATION FROM PLATINUM: R. S. Day and D. G. clifton

\section{A. General Discussion}

Two categories of plutonium contamination of platinum and its rhodium alloys are considered: first, a surface and/or near-surface type; second, a more deeply penetrating or diffusive type.

The first type of contamination can usually be cleaned off by chemical leaching, with or without electrolytic assistance.

The diffusive or more penetrating type of contamination requires more extensive chemical processing.

A literature search for platinum decontamination procedures revealed a patent (U.S. Patent No. 3,841,863, C. E. Caldwell and A. C. Ficklin, October 15, 1974), granted for the cleanup of uranium from platinum, that might apply to the plutonium case.

By this method, moiten lead and platinum are alloyed by heating. The alloy is solidified by cooling, selective dissolution is performed with an acid solution, and then upon filtration, the platinum is isolated as the precipitate. Rhodium alloys should behave similariy.

Figure 5 shows a binary phase diagram for the lead-platinum system. Also shown in Fig. 5, as a point of interest, is a horizontal dotted line at $1161 \mathrm{~K}$, the melting point of lead oxide ( $\mathrm{PbO}$ ).

The phase diagram shows lead with a melting point of $600.6 \mathrm{~K}$, forming a low-lying eutectic at $563 \mathrm{~K}$ between lead and the intermetallic compound, $\mathrm{Pb}_{4} \mathrm{Pt}$, so if enough lead is present and the temperature is high enough, the melt interacts with the platinum and forms a liquid phase.

The fate of a third element, such as plutonium in this type of a system, is contingent upon its chemical form. Conceivably, as metal it may enter the molten phase and alloy, or as an oxide, it may preferentially migrate to any oxide slags or refractories present.

B. Experiment

1. Exploratory Tests

Radioactively "cold" experiments were conducted to explore the proposed process. Lead-to-platinum ratios, crucible materials, heating 


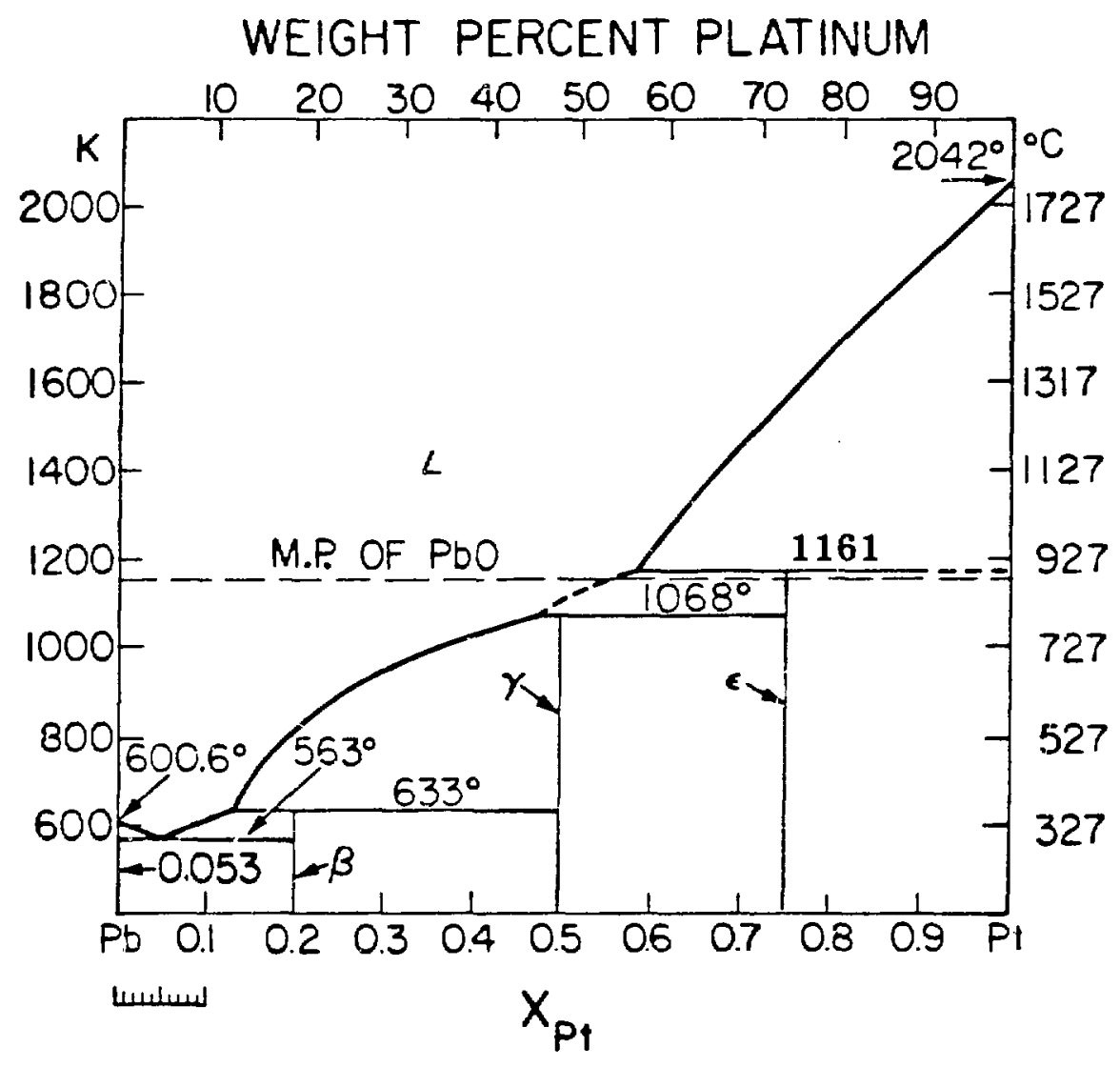

Fig. 5. Pb-Pt Phase Diagram. 
temperatures and times, furnace-atmosphere effects upon alloy button formation, and subsequent separation upon cooling were investigated: Also, button dissolution, platinum precipitation, and lead cleanup of the precipitate and its filterability were examined.

\section{Procedures}

A recipe that minimizes some experimental problems encountered and seems to optimize alloy button formation, subsequent selective dissolution, filtration, and lead disposal is shown as a flow sheet in Fig. 6 . This diagram also incorporates minor procedural changes resulting from later "hot" experiments. These changes are being used in the current process.

The procedure uses a 65:35 weight ratio for $\mathrm{Pb}: \mathrm{Pt}$ as a reasonable compromise to lower the quantity of lead needed and yet to allow good melting below $1000^{\circ} \mathrm{C}(1272 \mathrm{~K})$; other higher ratios are useable and may provide some mixing advantages, but these have not been studied extensively.

High-purity, high-fired $\mathrm{Al}_{2} \mathrm{O}_{3}$ crucibles are used for sample containment in a muffle furnace fitted with a tube through the door so it can be continually flooded with a slow stream of air, nitrogen, or argon. The sample is taken to $1000^{\circ} \mathrm{C}$ and held for at least 1 hour. After removal and cooling, the button is separated from the crucible and any slag and placed in a beaker for selective dissolution in $3-5 \underline{N} \mathrm{HNO}_{3}$. The platinum forms a finely divided black precipitate that is collected by filtration, thoroughly washed with $\sim 1-3 \underline{\mathrm{N}} \mathrm{HNO}_{3}$, and then dried. The; filtrate containing the lead and any dissolved plutonium is treated by any of several options before disposal.

\section{Comments}

Several very important features were defined in the initial "hot" tests:

It is absolutely necessary to have relatively "ccld" facilities such as a hood or glove box in which to perform the decontamination experiments. The original contaminated material is first cleaned of swipable contamination by leaching in $\sim 10 \mathrm{~N} \mathrm{HNO}_{3}$ containing a few drops of concentrated HF, rinsed, and dried. It is then moved to the "cold" 


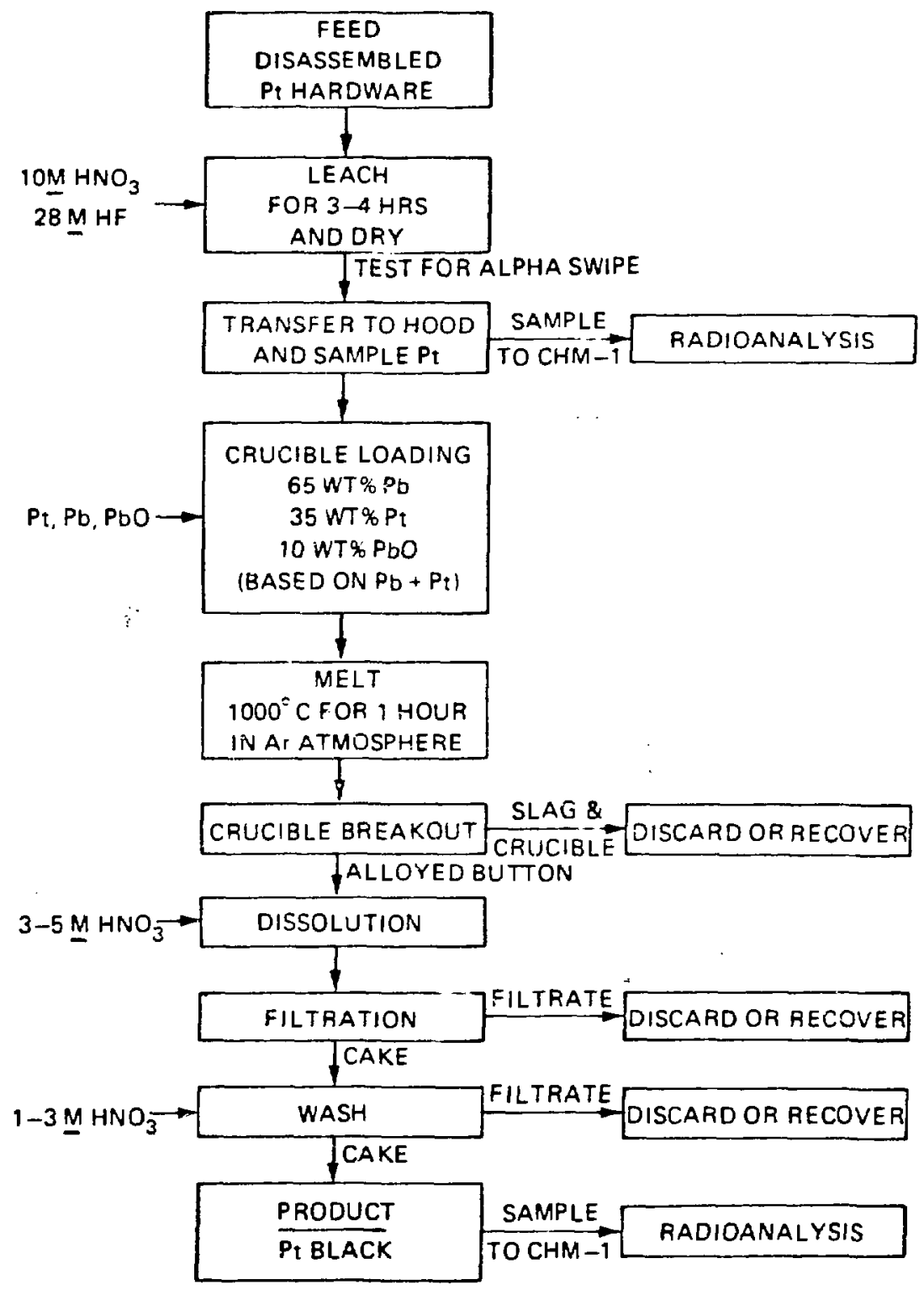

Fig. 6. Plutonium Decontamination from Platinum. 
hood where a sample is taken to determine its original contamination level, and the subsequent procedures are then carried out.

Experiments showed that nullite and graphite crucibles for holding samples did not give good alloys and decontamination, even in argon atmospheres, because of container and sample interaction.

- Determination of initial and final contamination of samples was best made by submitting appropriate samples for wet chemical analyses where the samples were heated to a constant weight, sampled, dissolved, and then assayed for plutonium and americium.

- A series of aliquot samples were taken of (1) the initial button-dissolution solution, (2) the plutonium black combined wash solutions, and (3) the combined solutions that were obtained from leaching slags and crucibles. These were placed on glass cover slips, evaporated, and $\alpha$-counted. The results showed unequivocally that the contamination was going to the slag and/or crucible. This result led to the use of added Pbo to serve as a getter-slag in later experiments.

\section{Results}

A number of decontamination experiments were performed using plutonium-contaminated platinum items taken from the storage vault.

Table III lists the experiments, lead-to-platinum weight ratios used in alloying, initial and recovered weights of plutonium, percentage change of the platinum weight, weight per cent of added lead oxide, initial and product platinum contamination as obtained by assays from CHM-1, comments, and decontamination factors found.

The decontamination factor (DF) is defined as the initial contamination of the platinum divided by the product contamination; both are expressed as grams of Pu per grams of Pt. This factor is considered a measurement of the success of decontamination efforts; the higher the factor the better the decontamination efficiency.

The first three experiments of Table III had $3.5,7.3$, and 15 wt addition of lead oxide ( $\mathrm{PbO}$ ) added to the lead and platinum mix before melting. These experiments were designed to examine the effects of varying slag quantities on decontamination efficiency. There is no obvious trend shown between the DFs and quantities of Pbo added. Upon reflection, this might be expected because only a small absolute value 
TABLE III

DECONTAMINATION EXXERIMENTS

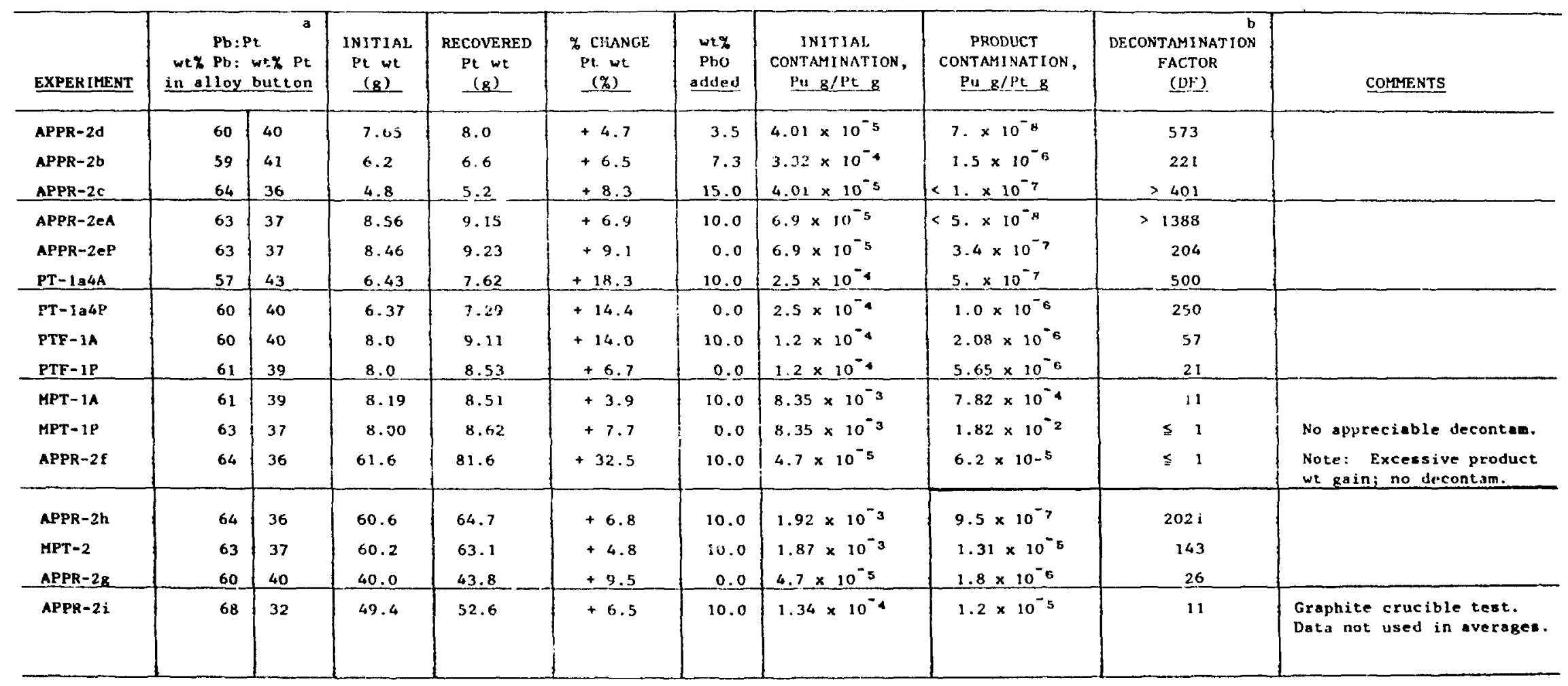

\section{- Estimated Pb:Pt in burton;}

Estimated $\mathrm{Pb} w t=$ Button we - Initial Pt wt

$$
w t \% \mathrm{~Pb}=\frac{\mathrm{Pb}_{\mathrm{w}} \mathrm{t}}{\text { Butcon wt }} \times 100
$$

$\omega$ wt\% Pt $=100-w t \% \mathrm{~Pb}$ b Decontamination Factor $=D F$ $D F=$ Initial Contamination product Contamination 
of plutonium is expected to be present as contaminant; hence, addition of slag beyond the minimally required amount for gettering would not necessarily increase the decontamination.

In the course of further experimentation, a value of 10 wt\% addition of $\mathrm{PbO}$ was arbitarily selected for testing; this was before assay results of the above experiments were obtained.

The next four experiments tabulated consist of two companion experiments in two sets. The only difference between the companion tests is that one had $10 \mathrm{wt} \% \mathrm{PbO}$ added. Examination of these four DFs shows higher DFs when Pbo is added.

The next group of four tests, PTF-1A and $-1 P$, and MPT-1A and $-1 P$, were to test the reproducibility of the decontaminations seen in the previous two sets. However, included as starting materials in the PTF case were platinum frit pieces similar to the earlier material but sampled from a different location; and in the MPT. tests, platinum from a flatware beaker was used. In both experimental sets, one each had 10 wt\% Pbo added. The DFs were lower than those previously found but still correlate with larger values occurring when $\mathrm{Pbo}$ is added.

Experiments APPR-2f, $-2 h$, and $-2 g$ were tests with scale-ups of from about 6 to 10 ; APPR-2f and $-2 \mathrm{~h}$ had $10 \mathrm{wt} \%$ PbO added and APPR $-2 \mathrm{~g}$ had no added Pbo. Discounting APPR-2 $f$ as a bad experiment because of its excessive weight gain of $\sim 33 \%$, we again see a higher DF for the case of added $\mathrm{Pbo}$.

Experiment MPT-2 was designed to reproduce APPR-2h in which a DF greater than 2000 was obtained; however, the DF for MPT-2 was on 1 y 143 .

Experiment APPR-2i was a scaled-up test performed in a graphite crucible with $10 \mathrm{wt} \%$ Pbo added and was run in an argon atmosphere. Even though $\mathrm{PbO}$ was added, very little slag was evident after the button was cooled and removed, so presumably a considerable amount of $\mathrm{Pbo}$ was reduced by the carbon; however, some decontamination occurred. (Data for APPR-2i are excluded from the discussion and conclusions given below.)

Al1 experiments in Table III show a weight gain of the product platinum over the initial sample. Gains of about 4 to $9 \%$ are assumed to occur because of absorption of gases or moisture on the extremely highsurface area of the powdered product material. Higher weight gains 
presumably are due to incomplete cleanup of the lead or possibly insufficient drying.

5. Conclusions

Reasonable decontamination was obtained in these experiments even though reproducibility was poor. The use of lead-oxide slag raised the decontamination factor in most cases. The problem in reproducibility is attributed to the difficulty in obtaining representative samples of the starting and product materials, thus causing less reliable assays.

In order to establish some numerical value for decontamination factors, the following averages are cited:

a) A straight average of all DFs gives DF $=338$.

b) An average obtained after dropping the two highes. (1388 and

2021 ) and the two lowest ( 1 and 1 ) DFs gives $\quad \underline{D F}=219$.

c) An average obtained by dropping the two highest and lowest (as per $b$ ) and all values obtained when no PbO was added gives DF $=272$.

d) An average obtained by dropping al1 DFs obtained when no $\mathrm{Pbo}$ was added gives $\underline{\mathrm{DF}}=531$.

Case c) with $D F=272$ is considered a conservative estimate for results to be expected in routine application of the process of Fig. 6 . 